Giroux, J.-F., J. Rodrigue, R. W. Brook, and M. Patenaude-Monette. 2022. Canada Goose populations harvested in Eastern James Bay by Eeyou Istchee Cree hunters. Avian Conservation and Ecology 17(1):5. https://doi.org/10.5751/ACE-02059-170105

Copyright (C) 2022 by the author(s). Published here under license by the Resilience Alliance.

Research Paper

\title{
Canada Goose populations harvested in Eastern James Bay by Eeyou Istchee Cree hunters
}

\author{
Jean-François Giroux ${ }^{1}$, Jean Rodrigue ${ }^{2}$, Rodney W. Brook ${ }^{3}$ and Martin Patenaude-Monette ${ }^{1}$ \\ ${ }^{1}$ Département des sciences biologiques, Université du Québec à Montréal, ${ }^{2}$ Canadian Wildlife Service, Environment and Climate \\ Change Canada, ${ }^{3}$ Ontario Ministry of Northern Development, Mines, Natural Resources and Forestry
}

\begin{abstract}
Canada Geese (Branta canadensis) are an important wildlife food resource for Cree people living in communities along the James Bay coasts. According to Traditional Ecological Knowledge, environmental changes along the coast have affected hunting success. Also, changes in the relative abundance of different goose populations that use James Bay may affect hunting opportunities. The objective of our study was to use band recoveries to identify Canada Goose populations harvested by Eeyou Istchee Cree hunters in their Eastern James Bay territory between 2000 and 2020. A total of 744 band recoveries were reported including 198 from the Atlantic Population (AP), 82 from the Southern Hudson Bay Population (SHBP), 122 from the Atlantic Flyway Resident Population (AFRP), 339 from the Mississippi Flyway Giant Population (MFGP), and three that could not be assigned to a population. The percentage of banded geese that were recovered was three times greater for the AP than for the other three populations. Eighty-seven percent of recoveries were reported in spring and $72 \%$ were submitted by hunters from the two northern communities (Chisasibi and Wemindji). Most recoveries were reported from coastal hunting sites, but a greater proportion of banded geese of the AP were recovered inland compared to the other goose populations, an indication of their propensity to migrate inland. The most noticeable change in the goose harvest compared to the 1970s was the rapid increase of molt migrant temperate-breeding geese of the AFRP and MFGP. In addition to environmental changes along the James Bay east coast, changes in the relative abundance of each goose population may affect hunting success because each population is differently susceptible to hunting within the territory due to differences in migratory behavior. Our study demonstrates the usefulness of band recoveries in tracking these changes and we therefore encourage agencies to maintain banding programs and Cree hunters to report their recovered bands.
\end{abstract}

\section{Populations de Bernaches du Canada récoltées par les chasseurs Cris d'Eeyou Istchee dans l'est de la Baie James}

RÉSUMÉ. Les Bernaches du Canada (Branta canadensis) sont une ressource alimentaire importante pour les populations Cris vivant le long des côtes de la Baie James. Selon les connaissances écologiques traditionnelles, les changements environnementaux côtiers ont influencé le succès de chasse. Les changements dans l'abondance relative des différentes populations de bernaches qui utilisent la Baie James peuvent aussi avoir affecté les opportunités de chasse. L'objectif de notre étude était d'utiliser les retours de bagues pour identifier les populations de Bernaches du Canada récoltées par les chasseurs Cris d'Eeyou Istchee dans le territoire est de la Baie James entre 2000 et 2020. Un total de 744 retours de bagues a été rapporté incluant 198 de la population de l'Atlantique (AP), 82 de la population du sud de la Baie d'Hudson (SHBP), 122 de la population résidente de la voie de migration de l'Atlantique (AFRP), 339 de la population de géantes de la voie de migration du Mississippi (MFGP) et trois qui n'ont pu être associés à une population. Le pourcentage de bernaches baguées qui furent récupérées était trois fois plus élevé pour l'AP que pour les autres populations. Quatre-vingt-sept pourcents des retours de bagues ont été rapportés au printemps et $72 \%$ le furent par les chasseurs des deux communautés nordiques (Chisasibi et Wemindji). La majorité des retours ont été récupérés dans des sites de chasse côtiers, mais une plus grande proportion de bernaches de l'AP furent récupérées à l'intérieur des terres comparativement aux autres populations, une indication de leur tendance à migrer à l'intérieur des terres. Le changement le plus marqué dans la récolte des bernaches par rapport aux années 1970s fut l'augmentation rapide des bernaches migratrices de mue qui nichent en milieu tempéré de l'AFRP et MFGP. En plus des changements environnementaux qui ont eu lieu le long de la côte est de la Baie James, les changements dans l'abondance relative de chaque population de bernaches a pu aussi affecter le succès de la récolte en raison de leur vulnérabilité respective à la chasse associée à leur comportement différent durant la migration. Notre étude démontre l'utilité des retours de bagues pour documenter ces changements et nous encourageons donc les différences agences à maintenir leurs programmes de baguage et les chasseurs Cris à rapporter les bagues récupérées.

Key Words: Atlantic flyway; band recovery; Branta canadensis; Canada Goose; Cree people; Eeyou Istchee; James Bay; Mississippi flyway; molt migration; subsistence hunting

Correspondent author: Jean-François Giroux, P.O. Box 8888, Stn centre-ville, Montréal, QC, Canada, H3C 3P8, giroux.jean-francois@uqam.ca 


\section{INTRODUCTION}

Canada Geese (Branta canadensis) are the main waterfowl harvested by Cree hunters from communities along the coast of James Bay and have been part of their subsistence hunting for centuries (Prevett et al. 1983, Berkes et al. 1994). The traditional annual spring goose break is important socially and culturally for all coastal communities of Eeyou Istchee, the Eastern James Bay Cree territory (Royer and Herrmann 2013). However, Eeyou Istchee hunters have reported a decline in the abundance of Canada Geese and a shift in their distribution from coastal to inland habitats (Herrmann et al. 2012). The construction of dams and river diversions for hydroelectricity production in the late 1970s in northern Quebec have altered the hydrology and water physico-chemistry in some sections of the James Bay east coast (Prinsenberg 1984). According to Traditional Ecological Knowledge (TEK), these changes have caused a decline of eelgrass (Zostera marina) abundance and have reduced food availability for Brant (Branta bernicla) and Canada Geese (Peloquin and Berkes 2009). Isostatic rebound (the process of postglacial uplift) is estimated at $10-12 \mathrm{~mm} /$ year in this region, which means that the coast has risen by about $60 \mathrm{~cm}$ during the last 60 years (Henton et al. 2006). This resulted in significant changes to the landscape and coastal plant communities such as a downward displacement of willows (Salix spp.; von Mörs and Bégin 1993). In addition to environmental changes along the James Bay east coast, changes in the relative abundance of different goose populations may affect hunting success.

Reed (1991) reported that more than $90 \%$ of Canada Geese harvested along the James Bay east coast in the 1970s were associated with the Mid-Atlantic Population, now referred to as the Atlantic Population (AP), and the rest were from the Southern James Bay (SJBP) and Mississippi Valley Populations (MVP), now referred to as the Southern Hudson Bay Population (SHBP; Fig. 1; U.S. Fish and Wildlife Service 2021). All these birds are considered B. c. interior subspecies, which are commonly called short-necked geese by Cree hunters (Royer and Herrmann 2011).

AP geese breed in Nunavik with concentrations along the Hudson Bay east coast and Ungava Bay west coast (U.S. Fish and Wildlife Service 2021; Harvey, Rodrigue, and Spangler, 2019 unpublished manuscript). In the mid-1990s, Malecki et al. (2001) showed that most AP geese tagged with satellite transmitters along Hudson Bay flew inland through Quebec during their southward fall migration. In spring, a few geese moved along the James Bay east coast when returning north, whereas a majority took an inland route. All geese tagged along Ungava Bay moved inland through Quebec during both migrations. SHBP geese breed in the Ontario and Manitoba portions of the Hudson Bay Lowland with concentrations along the James Bay west coast and on Akimiski Island, Nunavut (Fig. 1; Luukkonen and Leafloor 2017). Yearlings, sub-adults, and adults that have encountered a nesting failure can undertake a northeastward pre-molt migration to the Ungava Peninsula in late spring (Sterling and Dzubin 1967). These geese return from Nunavik in late summer and early fall to their southern wintering grounds.

The rapid growth of the Atlantic Flyway Resident Population (AFRP) and Mississippi Flyway Giant Population (MFGP) following their reintroduction in the 1950s and 1960s in temperate regions (Davies and Hindman 2008, Luukkonen and Leafloor
2017) has greatly expanded the distribution of Canada Geese in eastern North America. These birds breed in southern Canada and in every state of the Atlantic (AF) and Mississippi flyways (MF; Atlantic Flyway Council 2011, Luukkonen and Leafloor 2017). Molt migration of sub-adults and failed breeders to northern latitudes is well documented in AF and MF temperatebreeding geese (Zicus 1981, Abraham et al. 1999, Nichols et al. 2004, Sheaffer et al. 2007, Shirkey et al. 2018). They are referred to as long-necked geese by Cree hunters and are mostly composed of B. c. maxima that are noticeably larger than B. c. interior. Based on TEK, long-necked geese became more numerous in the Cree harvest around 2000 and are harvested later in spring than shortnecked geese (Royer and Herrmann 2011, Robus 2012).

Fig. 1. Approximate breeding ranges of Atlantic Flyway Resident Population (AFRP), Mississippi Flyway Giant Population (MFGP), Southern Hudson Bay Population (SHBP), and Atlantic Population (AP). Arrows represent approximate movements of molt migrants of AFRP, MFGP, and SHBP to the study area (adapted from U.S. Fish and Wildlife Service 2021). UB: Ungava Bay; HB: Hudson Bay; JB: James Bay.

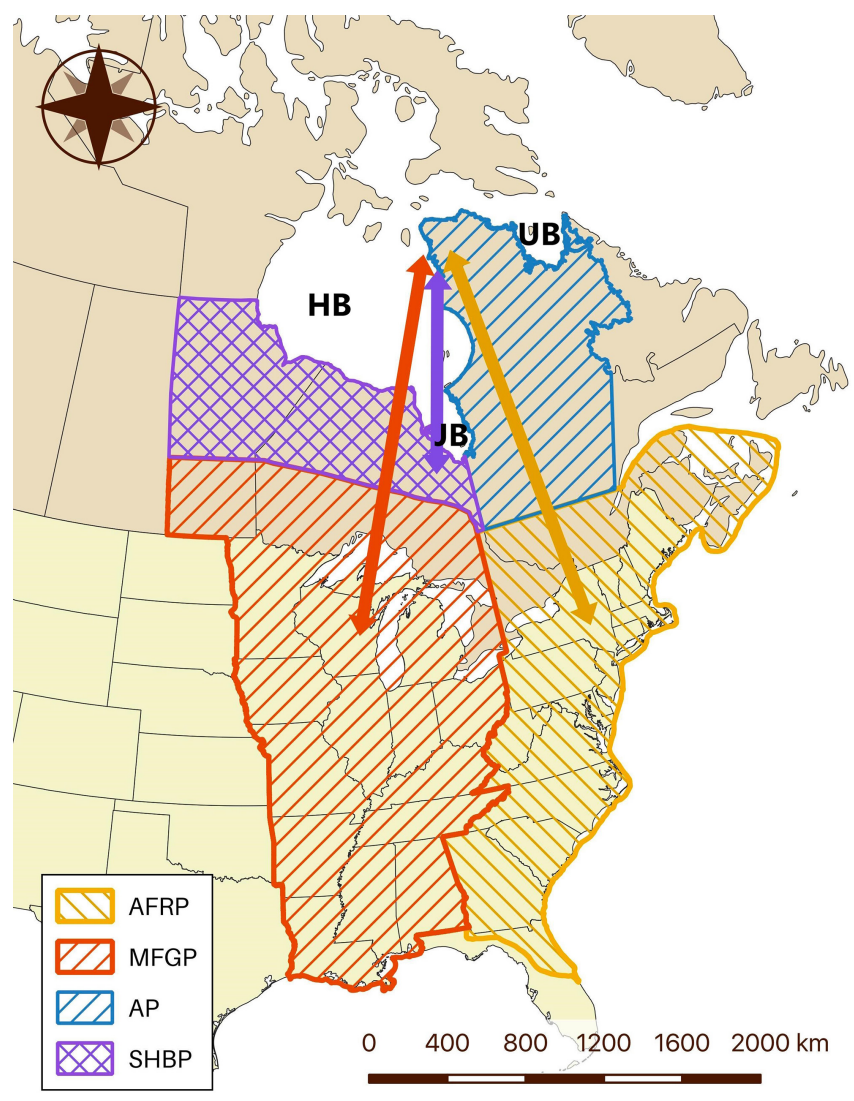

Our objective was to determine the different Canada Goose populations harvested in Eeyou Istchee James Bay territory using recoveries of leg-banded birds by Cree hunters. More specifically, we compared the percentage of bands recovered for each population and examined temporal trends during the last 20 years. We predicted that each goose population was harvested in 
different proportions between the spring and fall hunting seasons, between the southern and northern parts of the territory, and between coastal and inland hunting sites. We also predicted an increase in the proportion of recoveries of temperate-breeding geese. Differential vulnerability of each goose population to harvest because of differences in migratory behaviors could contribute to changes in hunting success.

\section{METHODS}

\section{Study area}

We obtained band recoveries from the United States Geological Survey (USGS) Bird Banding Laboratory (BBL) of Canada Geese harvested in an area of approximately $148,000 \mathrm{~km}^{2}$ located between $51^{\circ}$ and $55^{\circ} \mathrm{N}$ and $75^{\circ}$ and $80^{\circ} \mathrm{W}$ (Fig. 2). This area is part of Eeyou Istchee, the territory of the Cree Nation located primarily in northern Quebec. The territory covers approximately $400,000 \mathrm{~km}^{2}$ and includes the lands on the eastern shore of James Bay and south-eastern Hudson Bay, as well as the lakes and rivers that drain into them. The Eeyou Istchee territory is divided into traplines supervised by tallymen who are members of the Cree Trappers' Association of their respective communities.

Fig. 2. Location of the four Cree communities along James Bay east coast. The area delimited by the orange line represents the territory within Eeyou Istchee where Canada Goose (Branta canadensis) bands were recovered. Thin lines represent traplines established by the Cree Trappers' Association while the orange dashed line represents the limits between the southern and northern regions.

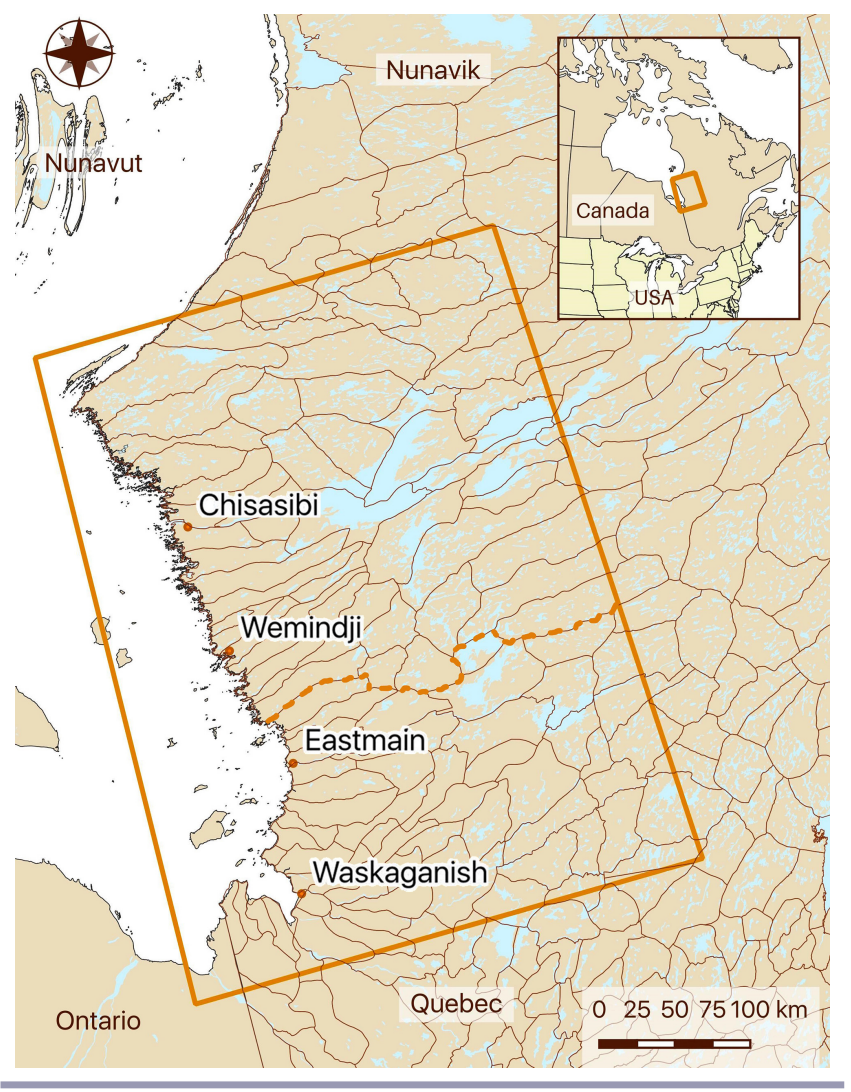

\section{Population affiliation}

We used the original banding information of each recovery to associate the harvested geese to the AF or MF and to the $B . c$. interior or B. c. maxima subspecies. We then used this information to identify whether the geese belong to AP, AFRP, SHBP, or MFGP based on nomenclature of U.S. Fish and Wildlife Service (2021). We retained direct and indirect recoveries of birds reported as being shot between 2000 and 2020, which included geese banded in summer (May-September) between 1987 and 2019. Direct recoveries included bands recovered during the fall, spring, and summer following the initial banding, whereas indirect recoveries included those recovered thereafter.

We considered geese banded in the United States between 1 May and 31 August as B. c. maxima, and we associated them to either the AFRP or MFGP based on the flyway affiliation of the state where they were banded (https://www.fws.gov/birds/management/ flyways.php). We associated geese banded in Ontario south of $50^{\circ}$ $\mathrm{N}$ and east of $80^{\circ} \mathrm{W}$ to AFRP and those banded west of that longitude to MFGP (R. J. Hughes, Canadian Wildlife Service, personal communication). No geese banded in southern Quebec were recovered along the James Bay east coast.

We classified recoveries of Canada Geese banded as flightless goslings and juveniles in northern Ontario $\left(\geq 51^{\circ} \mathrm{N}\right)$ and Nunavut as B. c. interior. We associated recoveries of geese banded as adults to a subspecies based on a combination of head measurements taken during banding operations (Moser and Rolley 1990, Merendino et al. 1994), the proportion of goslings in a catch, and breast color of geese (R. W. Brook, unpublished data). We retained the current criterion of the Mississippi Flyway Council establishing the breeding range boundary of the AF and MF $B$. c. interior in southern James Bay at the Ontario-Quebec border (79.5 ${ }^{\circ} \mathrm{W}$; Luukkonen and Leafloor 2017). We associated molt migrant B. c. maxima banded in northern Ontario and recovered in Eeyou Istchee to MFGP.

In Nunavik, Canada Geese have been captured along the Hudson Bay east coast and Ungava Bay west coast as part of an ongoing project started in 1997 that specifically aimed at catching family groups of AP geese. Geese banded as flightless goslings were classified as B. c. interior and associated with AP. Family groups do not usually mix with groups of molting adult and sub-adult geese, and most molt migrants have already regained flight during the August banding operations (S. S. Orichefsky, Canadian Wildlife Service, personal communication). Nevertheless, we cannot discount the possibility that a few molt migrants of the AFRP, MFGP, and SHBP were captured and banded during operations in Nunavik. To reduce potential bias, we classified adult geese as $B$. c . interior when captured in groups including $\geq$ $30 \%$ of goslings and categorized the others as unknown. Some geese harvested by Eeyou Istchee hunters had their head length measured when initially captured as adults in Nunavik and were therefore attributed to a subspecies using criteria established for AF Canada Geese (Beaumont 2007).

To appraise the relative importance of each population in the harvest, we considered the number of geese banded between 2000 and 2019 in the jurisdictions where at least one goose had been banded and recovered between 2000 and 2020. The data were retrieved from the BBL for temperate-breeding geese and from our own data sets for AP (JR) and SHBP (RWB). For each population, we added the number of geese banded in each 
jurisdiction and computed the proportion of banded geese recovered by Eeyou Istchee Cree hunters. We compared the proportion of bands recovered and reported among the four goose populations using a chi-square test and examined temporal trends in the percentage of bands reported for each population using simple linear regression analyses.

\section{Recovery date and location}

Many recoveries did not have an exact harvest date, and we therefore interpreted the inexact date codes as per BBL (https:// www.pwrc.usgs.gov/BBL/MANUAL/datecode.cfm) except for seasons that we established as spring (April-June), summer (July), and fall (August-November). Recoveries with R_month code 94 (Hunting Season), which corresponds to 1 September-31 March for BBL, were associated with the fall season, although some geese could have been harvested in spring. We associated recoveries of geese reported harvested from the coast up to $15 \mathrm{~km}$ inland to coastal habitats, and those reported harvested further inland were assigned to inland habitats. This distance was based on the daily movements of Canada Geese tagged with GPS neck collars that staged along the coast (J.-F. Giroux, unpublished data). We also divided the coast into a southern region by combining recoveries from the Waskaganish and Eastmain traplines and a northern region with recoveries from the Wemindji and Chisasibi traplines (Fig. 2). We compared the proportion of recoveries of the four goose populations between seasons and locations using chisquare tests.

\section{RESULTS}

Between 2000 and 2020, 744 banded Canada Geese were harvested in the Eeyou Istchee James Bay territory and reported to BBL. We were able to assign a population to $99.6 \%$ of recoveries including 198 geese associated with the AP, 82 with the SHBP, 122 with the AFRP, and 339 with the MFGP. These geese had been originally banded in 14 states, three provinces, and one territory of the AF and MF (Table 1). More specifically, 93.4\% of recovered AP geese were banded along the Hudson Bay east coast and the rest along the Ungava Bay west coast. Recovered SHBP geese were banded along the southwestern coast of James Bay in Ontario (78.0\%), on Akimiski Island in Nunavut (20.7\%), and along the west shore of Hudson Bay in Manitoba (1.2\%). A majority of recovered AFRP geese were banded in southeastern Ontario (40.9\%), Pennsylvania (20.5\%), and New York (21.3\%). Finally, MFGP geese recovered in Eeyou Istchee were predominantly banded in Ohio (41.9\%), southwestern Ontario (33.3\%), and Michigan (18.9\%).

The number of band recoveries depends on the number of geese banded, which greatly varied among the four populations (Table 2). A much greater number of temperate-breeding geese, especially in the MF, have been banded during the 2000-2019 period compared to numbers for AP and SHBP. Nevertheless, the proportion of AP banded geese that were recovered and reported to BBL was nearly three times greater than for the other three populations $\left(\chi^{2}=137.9, \mathrm{df}=3, P<0.001\right.$; Table 2$)$. The percentage of bands reported for both populations of temperate-breeding geese and for SHBP significantly increased during the study period (AFRP: $\mathrm{r}^{2}=0.32, \mathrm{~F}_{1,18}=8.59, P=0.009$; MFGP: $\mathrm{r}^{2}=$ $0.48, \mathrm{~F}_{1,18}=16.46, P<0.001$; $\mathrm{SHBP}: \mathrm{r}^{2}=0.33, \mathrm{~F}_{1,18}=8.74, P=$ $0.008)$, whereas no such trend was observed for AP geese $(P=$ $0.12)$.
Table 1. Number (N) of Canada Goose (Branta canadensis) band recoveries within the Eeyou Istchee James Bay territory according to population affiliation and the original banding jurisdiction, 2000-2020.

\begin{tabular}{|c|c|c|}
\hline Population $^{\dagger}$ & Jurisdiction & $\mathrm{N}$ recoveries \\
\hline \multirow[t]{10}{*}{ AFRP } & Maryland & 1 \\
\hline & New Jersey & 1 \\
\hline & New York & 26 \\
\hline & Pennsylvania & 25 \\
\hline & Quebec (Hudson Bay) & 5 \\
\hline & Southern Ontario (east) & 50 \\
\hline & Vermont & 2 \\
\hline & Virginia & 9 \\
\hline & West Virginia & 3 \\
\hline & Subtotal & 122 \\
\hline \multirow[t]{11}{*}{ MFGP } & Illinois & 1 \\
\hline & Indiana & 5 \\
\hline & Iowa & 1 \\
\hline & Kentucky & 5 \\
\hline & Michigan & 64 \\
\hline & Northern Ontario & 4 \\
\hline & Nunavut & 3 \\
\hline & Ohio & 142 \\
\hline & Southern Ontario (west) & 113 \\
\hline & Wisconsin & 1 \\
\hline & Subtotal & 339 \\
\hline \multirow[t]{3}{*}{ AP } & Quebec (Hudson Bay) & 185 \\
\hline & Quebec (Ungava Bay) & 13 \\
\hline & Subtotal & 198 \\
\hline \multirow[t]{5}{*}{ SHBP } & Manitoba & 1 \\
\hline & Nunavut & 17 \\
\hline & Northern Ontario & 64 \\
\hline & Subtotal & 82 \\
\hline & TOTAL & 741 \\
\hline
\end{tabular}

${ }^{\dagger}$ Atlantic Flyway Resident Population (AFRP), Mississippi Flyway Giant Population (MFGP), Atlantic Population (AP), and Southern Hudson Bay Population (SHBP).

Table 2. Number of Canada Goose (Branta canadensis) bands recovered within the Eeyou Istchee James Bay territory according to population affiliation between 2000 and 2020, and the number of geese banded for each population between 2000 and 2019.

\begin{tabular}{lccc}
\hline \hline Population $^{\dagger}$ & Band recoveries & Banded geese $^{*}$ & \% bands recovered \\
\hline AFRP & 97 & 259634 & 0.04 \\
MFGP & 260 & 473105 & 0.05 \\
AP & 137 & 98609 & 0.14 \\
SHBP & 57 & 131700 & 0.04 \\
TOTAL & 551 & 963048 & 0.06 \\
\hline
\end{tabular}

${ }^{\dagger}$ Atlantic Flyway Resident Population (AFRP), Mississippi Flyway Giant Population (MFGP), Atlantic Population (AP), and Southern Hudson Bay Population (SHBP).

* Total number of geese banded in the jurisdictions where at least one recovered goose was banded.

The season when the harvest took place was known for $82.6 \%$ of recoveries with $86.6 \%$ reported in spring, $12.6 \%$ in fall, and $0.8 \%$ in summer. A slightly but significantly greater proportion of AP and SHBP bands were recovered in spring compared to AFRP and MFGP geese $\left(\chi^{2}=15.8, \mathrm{df}=3, P=0.001\right.$; Fig. 3$)$. The median dates of spring recoveries for SHBP, AP, MFGP, and AFRP geese 
Fig. 3. Recoveries of banded Canada Geese (Branta canadensis) of Atlantic Flyway Resident Population (AFRP), Mississippi Flyway Giant Population (MFGP), Southern Hudson Bay Population (SHBP), and Atlantic Population (AP) reported by hunters of the Eeyou Istchee James Bay territory in spring and fall, 2000-2020. Numbers of recoveries in parentheses.

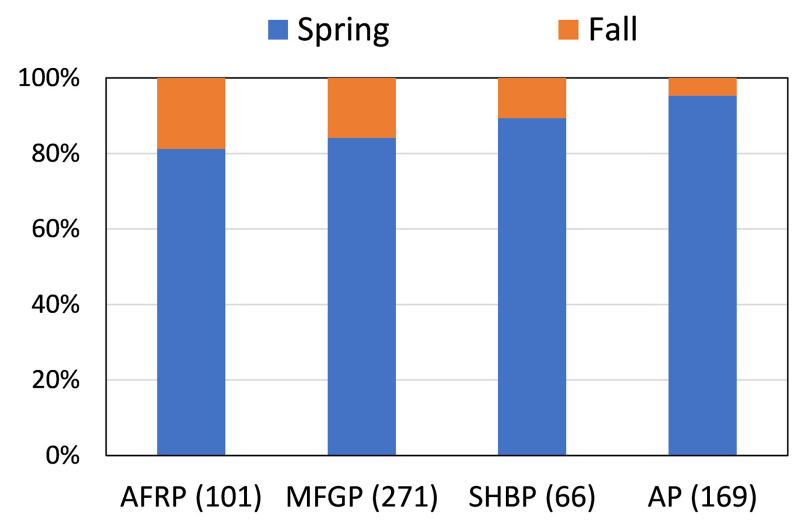

were respectively 28 April, 12 May, 7 June, and 8 June. The median dates of fall recoveries were 5 September for both AFRP and MFGP, 23 September for SHBP, and 2 October for AP geese.

Hunters from Wemindji and Chisasibi, the two northern communities, reported $71.7 \%$ of all recoveries. A greater proportion of recoveries of AP, AFRP, and MFGP geese were reported in the north, whereas $\mathrm{SHBP}$ geese were mostly recovered in the southern part of James Bay $\left(\chi^{2}=172.9, \mathrm{df}=3, P<0.001\right.$; Fig. 4). In fact, $69.2 \%$ of the recovered SHBP banded geese were shot south of Waskaganish near the Quebec-Ontario border (Fig. 2). Finally, $76.3 \%$ of all recoveries were from geese harvested along the coast. However, there was a greater proportion of inland recoveries for AP and SHBP than for AFRP and MFGP $\left(\chi^{2}=\right.$ 19.1, df $=3, P<0.001$; Fig. 5).

\section{DISCUSSION}

In the 1970s, Canada Geese harvested in the James Bay area and northern Quebec were associated with the AP and SHBP (Reed, 1984, unpublished manuscript). Using recoveries of leg-banded birds by Cree hunters, we established that molt migrant temperatebreeding geese of the AFRP and MFGP are now also harvested in the Eeyou Istchee James Bay territory. The proportion of banded geese recovered was greatest for the AP but did not change over time, whereas it increased for the other three populations. The proportion of bands recovered and reported for each population provides insight about temporal changes but does not allow assessing the relative contribution of each population to the harvest.

We found that $87 \%$ of banded geese were recovered in spring. The spring goose break is an important socio-cultural event in Cree communities (Hanson and Currie 1957, Prevett et al. 1983, Royer and Herrmann 2013). One reason that promoted this century-old tradition is that geese are fatter in spring than in fall. Reed (1991) estimated that $58 \%$ of the annual goose kill between 1972 and 1979 occurred in spring and the rest in fall. According to TEK,
Fig. 4. Recoveries of banded Canada Geese (Branta canadensis) of Atlantic Flyway Resident Population (AFRP), Mississippi Flyway Giant Population (MFGP), Southern Hudson Bay Population (SHBP), and Atlantic Population (AP) reported by hunters from Waskaganish and Eastmain (southern communities) and Wemindji and Chisasibi (northern communities), 2000-2020 (see Fig. 2). Numbers of recoveries in parentheses.

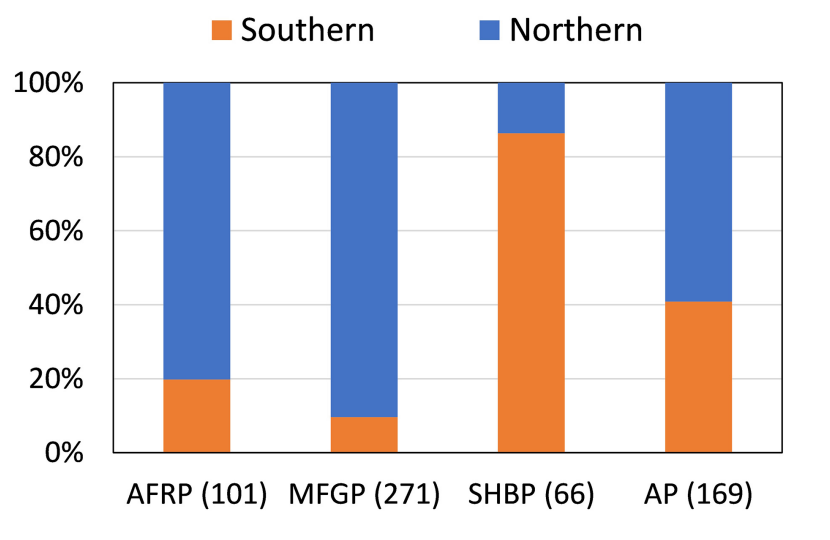

Fig. 5. Recoveries of banded Canada Geese (Branta canadensis) of Atlantic Flyway Resident Population (AFRP), Mississippi Flyway Giant Population (MFGP), Southern Hudson Bay Population (SHBP), and Atlantic Population (AP) reported in coastal and inland hunting sites in Eeyou Istchee James Bay territory, 2000-2020. Numbers of recoveries in parentheses.

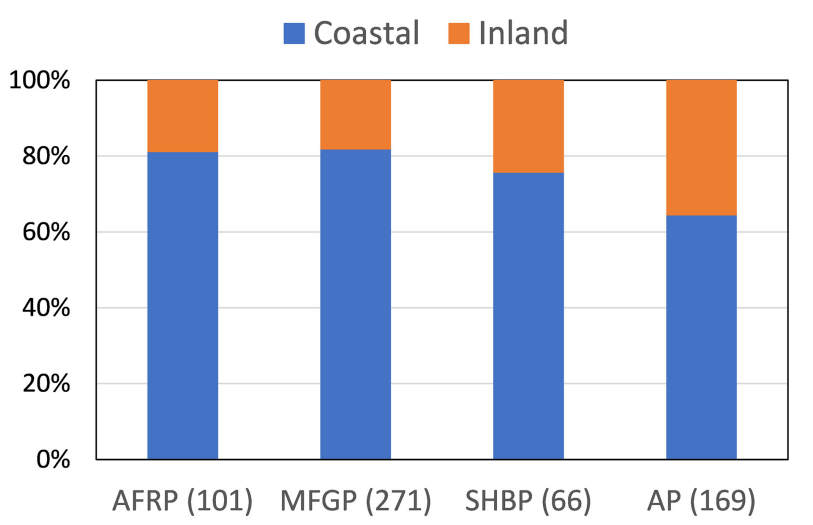

goose hunting in fall has had less participation in recent years because it is less successful. This has been attributed to deteriorating habitat conditions and a shift in migration routes of geese (Peloquin and Berkes 2009). Changes in the Cree way of life may have also reduced the time available for waterfowl hunting activities in fall. Robus (2012) reported that Cree people of James Bay are now relying to a greater extent on wage labor and therefore cannot allocate as much time to traditional activities.

A greater proportion of recoveries for AP and SHBP geese were reported in spring than for MFGP and AFRP geese. In 2018- 
2019, short-necked geese represented $85.6 \%$ of 5644 Canada Geese shot in spring and tallied in harvest booklets filled by Eeyou Istchee hunters (J.-F. Giroux, unpublished data). Small individuals of $B$. c. maxima can be confused with large individuals of $B$. $c$. interior, whereas male $B$. c. interior are almost the same size as female B. c. maxima. Misidentifications of the two subspecies are thus possible. However, the spring goose break extended from the last week of April in the southern part of the territory to the second week of May in the northern part, and this coincided with recovery dates of AP and SHBP banded geese. Long-necked geese were reported to be harvested during the first two weeks of June after the goose break, and this concurred with the recovery dates of AFRP and MFGP banded geese. Returning temperatebreeding geese that migrated north to molt represented $48.0 \%$ of 225 geese shot in fall 2018-2019 and reported in harvest booklets (J.-F. Giroux, unpublished data). The fall hunting season is spread over several weeks, allowing the harvest of temperate-breeding geese that migrate south earlier than AP geese.

The percentage of AFRP and MFGP banded geese that were recovered by Cree hunters increased between 2000 and 2020. The presence of temperate-breeding geese in Eeyou Istchee harvest coincided with the rapid increase of these populations following their reintroduction in temperate regions (Davies and Hindman 2008, Luukkonen and Leafloor 2017). It is believed that much of the nesting habitat in southern Ontario has become saturated and, as a result, it is possible that the average age of first nesting has increased, potentially increasing the number of non-breeding adult geese that undergo a molt migration (C. Sharp, Canadian Wildlife Service, personal communication). Beaumont et al. (2018) found that females that had their nests removed or whose nests failed (e.g., predation) had a greater probability of leaving their breeding area in southern Quebec to molt than females that were successful or had their eggs treated with oil. Luukkonen et al. (2008) estimated that more than half of the MFGP could undergo a molt migration in any given year, but the exact proportion remains unknown. The number of nests destroyed by management programs in the U.S. portion of the MF has increased by 61\% per year between 1995 and 2012 (Luukkonen and Leafloor 2017). In southern Ontario, the number of permits issued to control Canada Goose nests increased by $4 \%$ per year between 2007 and 2019 (C. Sharp, Canadian Wildlife Service, personal communication). These measures may elicit more temperate-breeding geese to undertake a molt migration, thus increasing the number of molt migrants susceptible to be harvested by Eeyou Istchee hunters.

Hunters from Wemindji and Chisasibi located in the northern part of the James Bay east coast reported $72 \%$ of all recovered banded geese. Although the number of active goose hunters in each community is unknown, data from Statistics Canada indicate that $65 \%$ of the region's population inhabit these two communities. Assuming that reporting rates were similar across the four communities, the goose harvest appears to be roughly proportional to the number of inhabitants and probably of goose hunters in each community that have access to similar resources for reporting recovered bands (e.g., Internet and phone access).

Most band recoveries occurred along the coast, but there was a greater proportion of AP geese shot inland compared to AFRP or MFGP. Recent GPS tracking of Canada Geese breeding in the
Puvirnituk area showed that all marked birds migrated inland during their fall migration (J.-F Giroux, unpublished data), confirming the observations of Malecki et al. (2001) in the mid-1990s. Because of greater access to inland hunting sites with the development of road network in the second half of the 1990s associated with hydro-electric developments (Peloquin and Berkes 2009), some Eeyou Istchee hunters have taken advantage of this inland migration route. Inland hunters can also avoid competition in the more heavily hunted coastal areas as community populations grew, a phenomenon observed in the Ontario Hudson Bay Lowlands (K. F. Abraham, personal communication).

For many years, Cree hunters have created attractive sites for waterfowl hunting by constructing small impoundments and clearing trees to create coastal corridors known as tuuhiikaan (Reed 1991, Sayles and Mulrennan 2010). Despite these management efforts, Eeyou Istchee hunters who hunt along the coast claim that goose hunting is not as good as it was in the past. They attribute the harvest decline to environmental changes, the most often cited being the decline of eelgrass abundance. Some hunters interviewed by Peloquin and Berkes (2009) in eastern James Bay and by Robus (2012) in western James Bay believed that changes in hunting practices (e.g., shooting after dusk, hunting every day without letting geese rest, and use of helicopters to reach hunting camps) may have reduced hunting success. Using calculations based on data from Statistics Canada, the number of inhabitants in the four Cree communities of the James Bay east coast has doubled in the last 30 years, reaching 10,000 individuals in 2021. This might have increased hunting pressure, a phenomenon observed in western James Bay (Robus 2012). Changes in distribution and relative abundance of different populations of Canada Geese that migrate through the Eeyou Istchee James Bay territory may also influence hunting opportunities.

\section{CONCLUSION}

Our results confirm that changes in goose populations harvested by Cree hunters in Eeyou Istchee have occurred since the 1970s and are still occurring. The main change has been an increase of molt migrant temperate-breeding geese associated with the Atlantic and Mississippi Flyways. The relative contribution of each goose population to the harvest remains to be established, and biologists should work together with Cree hunters and their association to determine the number of geese harvested on the Eeyou Istchee territory. This is necessary to complement the information obtained in other regions of the flyways and to insure sustainability of the harvest. Our study shows that band returns can be useful to inform Indigenous communities about changes in Canada Goose populations that use their territory. This could become a motivation to take a greater role in the management of these goose populations at the flyway level. As Cree communities are becoming increasingly connected to the Internet, hunters should be encouraged to use the USGS web site for reporting band returns. Information should be disseminated within communities that shooting a banded goose is not a regulation violation, and that reporting bands to $\mathrm{BBL}$ contributes to population management of Canada Geese. Once this is well established, it would be pertinent to determine a band reporting rate of Cree hunters, which is currently unknown (Klimstra and Padding 2012). 
With the predicted climate changes and potential impact on the coastal habitats along James Bay, it is important to maintain and expand the various banding programs to track any changes in the goose populations harvested in Eeyou Istchee. Each goose population likely exhibits a different behavior during migration and may change their behavior differently in response to environmental changes. For instance, goose populations that breed locally or migrate early to more northerly breeding range may have different movement patterns than those that arrive later and leave earlier once molt is complete. This could have a direct impact on hunting success in Eeyou Istchee and influence the overall harvest of each population. We recommend a comparison of migration characteristics of temperate and sub-arctic nesting geese in terms of flight altitude, timing during the day, distance from coast, habitats used, and the number and duration of staging periods.

Responses to this article can be read online at: https://www.ace-eco.org/issues/responses.php/2059

\section{Author Contributions:}

$J F G, J R$, and MPM designed the study and retrieved the data. RWB provided data. JFG wrote the manuscript that was reviewed and edited by JR, RB, and MPM. MPM prepared the figures.

\section{Acknowledgments:}

We first and foremost thank all Eeyou Istchee Cree hunters who reported bands that they recovered on Canada Geese during their subsistence hunting. Without their contribution, this study would not have been possible. We thank M. Dunn, J.-P. Gilbert, and E. Sinave for their continuous support and for facilitating the collaboration with Cree communities. This study was financially supported by the Niskamoon Corporation as part of the Coastal Habitat Research Program. We are grateful to D. Avers, J. H. Brunjes, P. M. Castelli, G. Costanzo, W. R. Gates, W. F. Harvey, D. J. Holm, D. L. Howell, R. J. Hughes, J. M. Krapfl, D. R. Luukkonen, T. C. Nichols, P. I. Padding, C. Sharp, B. Shirkey, J. Stempka, J. Stiller, N. Stricker, R. M. Wheat, and M. Whitbeck for sharing their knowledge about Canada Goose banding programs across the AF and MF. Finally, we thank K. F. Abraham, R. Courcelles, J. Idrobo, and two anonymous reviewers for their constructive comments on the manuscript.

\section{LITERATURE CITED}

Abraham, K. F., J. O. Leafloor, and D. H. Rusch. 1999. Molt migrant Canada Geese in northern Ontario and western James Bay. Journal of Wildlife Management 63:649-655. https://doi. org/10.2307/3802654

Atlantic Flyway Council. 2011. Atlantic Flyway resident population Canada Goose management plan. Atlantic Flyway Council, Washington, D.C., USA. [online] URL: https://www. dec.ny.gov/docs/wildlife_pdf/atlanticflywaygoose.pdf
Beaumont, M. 2007. Distribution de la bernache résidente (Branta canadensis maxima) dans le sud du Québec. M.Sc. Thesis. Université du Québec à Montréal, Montreal, Québec, Canada. https://central.bac-lac.gc.ca/.item?id=TC-QMUQ-3254\&op=pdf\&app= Library\&oclc_number $=757411302$

Beaumont, M., J. Rodrigue, C. Pilotte, É. Chalifour, and J.-F. Giroux. 2018. Behavioral response of Canada Geese to egg-oiling and nest removal. Journal of Wildlife Management 82:1359-1366. https://doi.org/10.1002/jwmg.21486

Berkes, F., P. J. George, R. J. Preston, A. Hughes, J. Turner, and B. D. Cummins. 1994. Wildlife harvesting and sustainable regional native economy in the Hudson and James Bay Lowland, Ontario. Arctic 47:350-360. https://www.jstor.org/stable/40511596

Davies, J., and L. Hindman, editors. 2008. A management plan for the Atlantic population of Canada Geese. Atlantic Flyway Council.

Hanson, H. C., and C. Currie. 1957. The kill of wild geese by the natives of the Hudson-James Bay region. Arctic 10:211-229. https://www.jstor.org/stable/40506768

Henton, J. A., M. R. Craymer, H. Dragert, S. Mazzotti, R. Ferland, H. Dragert, S. Mazzotti, and D. L. Forbes. 2006. Crustal motion and deformation monitoring of the Canadian landmass. Geomatica 60:173-191. [online] URL: https://cdnsciencepub. com/doi/abs/10.5623/geomat-2006-0021

Herrmann, T. M., M.-J. S. Royer, and R. Cuciurean. 2012. Understanding subarctic wildlife in Eastern James Bay under changing climatic and socio-environmental conditions: bringing together Cree hunters' ecological knowledge and scientific observations. Polar Geography 35:245-270. https://doi. org/10.1080/1088937X.2011.654356

Klimstra, J. D., and P. I. Padding. 2012. Harvest distribution and derivation of Atlantic Flyway Canada Geese. Journal of Fish and Wildlife Management 3:43-55. https://doi.org/10.3996/032011JFWM-023

Luukkonen, D., and J. Leafloor, editors. 2017. A management plan for Mississippi Flyway Canada Geese. Mississippi Flyway Council. [online] URL: https://www.agjv.ca/wp-content/uploads/2019/02/ Mgmt-Plan-MF-Canada-Goose.pdf

Luukkonen, D. R., H. H. Prince, and R. C. Mykut. 2008. Movements and survival of molt migrant Canada Geese from southern Michigan. Journal of Wildlife Management 72:449-462 https://doi.org/10.2193/2007-029

Malecki, R. A., B. D. J. Batt, and S. E. Sheaffer. 2001. Spatial and temporal distribution of Atlantic population Canada Geese. Journal of Wildlife Management 65:242-247. https://doi. org/10.2307/3802903

Merendino, M. T., C. D. Ankney, D. G. Dennis, and J. O. Leafloor. 1994. Morphometric discrimination of giant and Akimiski Island Canada Geese. Wildlife Society Bulletin 22:14-19. https://www. jstor.org/stable/3783216

Moser, T. J., and R. E. Rolley. 1990. Discrimination of giant and interior Canada Geese of the Mississippi Flyway. Wildlife Society Bulletin 18:381-388. https://www.jstor.org/stable/3782735 
Nichols, T. C., N. L. Zimpfer, R. V. Raftovich, and P. M. Castelli. 2004. Molt migration of New Jersey resident Canada Geese. Pages 169-177 in T. J. Moser, R. D. Lien, K. C. VerCauteren, K. F. Abraham, D. E. Andersen, J. G. Bruggink, J. M. Collucy, D. A. Graber, J. O. Leafloor, D. R. Luukkonen, and R. E. Trost, editors. Proceedings of the 2003 International Canada Goose Symposium, Madison, Wisconsin, USA.

Peloquin, C., and F. Berkes. 2009. Local knowledge, subsistence harvests, and social-ecological complexity in James Bay. Human Ecology 37:533-545. https://doi.org/10.1007/s10745-009-9255-0

Prevett, J. P., H. G. Lumsden, and F. C. Johnson. 1983. Waterfowl kill by Cree hunters of the Hudson Bay Lowland, Ontario. Arctic 36:185-192. https://www.jstor.org/stable/40509570

Prinsenberg, S. 1984. Freshwater contents and heat budgets of James Bay and Hudson Bay. Continental Shelf Research 3:191-200. "https://doi.org/10.1016/0278-4343(84)90007-4"

Reed, A. 1991. Subsistence harvesting of waterfowl in northern Quebec: goose hunting and the James Bay Cree. Pages 344-349 in R. E. McCabe, editor. Transactions of the 56th North American Wildlife and Natural Resources Conference. Wildlife Management Institute, Washington, D.C., USA.

Robus, J. 2012. Linking two ways of knowing to understand climate change impacts on geese and First Nations in the Hudson Bay Lowland. Thesis. Trent University, Peterborough, Ontario, Canada. [online] URL: https://www.collectionscanada.gc.ca/obj/ thesescanada/vol2/002/MR82892.PDF

Royer, M.-J. S., and T. M. Herrmann. 2011. Socioenvironmental changes in two traditional food species of the Cree First Nation of subarctic James Bay. Cahiers de géographie du Québec 55:575-601. https://doi.org/10.7202/1008895ar

Royer, M.-J. S., and T. M. Herrmann. 2013. Cree hunters' observations on resources in the landscape in the context of socioenvironmental change in the eastern James Bay. Landscape Research 38:443-460. https://doi.org/10.1080/01426397.2012.722612

Sayles, J. S., and M. E. Mulrennan. 2010. Securing a future: Cree hunters' resistance and flexibility to environmental changes, Wemindji, James Bay. Ecology and Society 15(4):22. https://doi. org/10.5751/ES-03828-150422

Sheaffer, S. E., R. A. Malecki, B. L. Swift, J. Dunn, and K. Scribner. 2007. Management implications of molt migration by the Atlantic Flyway resident population of Canada Geese, Branta canadensis. Canadian Field-Naturalist 121:313-320. https://doi. org/10.22621/cfn.v121i3.481

Shirkey, B. T., R. J. Gates, and M. D. Ervin. 2018. Survival rates and harvest patterns of Ohio-banded Canada Geese. Wildlife Society Bulletin 42:394-402. https://doi.org/10.1002/wsb.893
Sterling, T., and A. Dzubin. 1967. Canada Goose molt migrations. Pages 355-373 in Transactions of the 32nd North American Wildlife and Natural Resources Conference. Wildlife Management Institute, Washington, D.C., USA.

U.S. Fish and Wildlife Service. 2021. Waterfowl population status, 2021. U.S. Department of the Interior, Washington, D.C., USA. https://www.fws.gov/migratorybirds/pdf/surveys-and-data/Populationstatus/Waterfowl/WaterfowlPopulationStatusReport21.pdf

von Mörs, I., and Y. Bégin. 1993. Shoreline shrub population extension in response to recent isostatic rebound in eastern Hudson Bay, Quebec, Canada. Arctic and Alpine Research 25:15-23. https://doi.org/10.2307/1551475

Zicus, M. C. 1981. Molt migration of Canada Geese from Crex Meadows, Wisconsin. Journal of Wildlife Management 45:54-63. https://doi.org/10.2307/3807873
Editor-in-Chief: Alexander L.Bond Subject Editor: Auriel M.V.Fournier

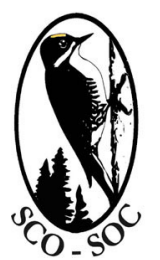

Sponsored by the Society of Canadian Ornithologists and Birds Canada

Parrainée par la Société des ornithologistes du Canada et Oiseaux Canada

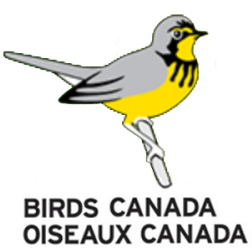

